\title{
Production and some properties of extracellular phytase from Thermomyces lanuginosus IMI 096218 on rice flour as substrate
}

\author{
Bujna E, Rezessy-Szabó JM, Nguyen DV and Nguyen DQ
}

Institute of Bioengineering and Process Engineering, Faculty of Food Science, Szent István University, Ménesi út 45. 1118 Budapest, Hungary

Bujna E, Rezessy-Szabó JM, Nguyen DV, Nguyen DQ 2016 - Production and some properties of extracellular phytase from Thermomyces lanuginosus IMI 096218 on rice flour as substrate. Mycosphere 7(10), 1576-1587, Doi 10.5943/mycosphere/si/3b/9

\begin{abstract}
Thermophilic fungi Thermomyces lanuginosus IMI 096218 strain produces phytase enzyme on rice flour in submerged fermentation. The maximal activity was achieved on the $4^{\text {th }}$ day of fermentation using $5(\mathrm{w} / \mathrm{v}) \%$ rice flour and at 220-rpm agitation speed. Additionally, the enzyme production was enhanced by supplementation of $0.1 \%$ Tween-80 detergent into fermentation medium. The phytase was purified about 9.1 fold with yield of $5.1 \%$. The optimal $\mathrm{pH}$ and temperature of the purified phytase enzyme were $\mathrm{pH} 5.5$ and $70^{\circ} \mathrm{C}$, respectively. The half-life times of enzyme at temperature $54-58^{\circ} \mathrm{C}$ and $\mathrm{pH}$ range 5.0-7.5 were longer than $100 \mathrm{~min}$. Kinetic parameters of phytase on sodium-phytate substrate were determined by linear Lineweaver-Burk plot: $\mathrm{KM}=0.285 \mathrm{mM}, \mathrm{V}_{\max }=0.126 \mathrm{mM} / \mathrm{min}$, and Hanes-Woolf plot: $\mathrm{KM}=0.312 \mathrm{mM}$, Vmax $=0.132$ $\mathrm{mM} / \mathrm{min}$, respectively. The presence of $5 \mathrm{mM} \mathrm{Zn}{ }^{2+}, \mathrm{Ag}^{+}, \mathrm{Co}^{2+}$ and $\mathrm{Cu}^{2+}$ ions strongly inhibited the enzyme reaction. The residual activities were 55\%, 49\%, 38\% and 34\% respectively. This phytase can be considered as a potential candidate in animal feeding as well as in the production of some intermediates for clinical applications.
\end{abstract}

Key words - characterisation - degradation of phytic acid - kinetic constants - submerged fermentation - natural substrate - purification

\section{Introduction}

Phosphorous is one of the most essential elements in the energy metabolism and it plays an important role in the growth and health status of bone. Phosphorous is basic compound in nucleic acids, ATP and phospholipids. For animals and human phosphorus-containing water and plants are the main sources of phosphorus in their diet. In the plant kingdom, phytic acid is a storage form of phosphorus, which is presence in different amount depending on vegetable raw materials. Cereal grains, legumes and oil seeds contain 1.4-55.1 g/mg phytic acid (Konietzny \& Greiner 2003). The feedstuffs originating from plant contain about $60-90 \%$ of their total phosphorus content in the form of phytate (Loewus 2002). Phytic acid and its salts are anti-nutritional factors, because they have the ability to chelate various essential divalent metal ions blocking or slowing down their absorption and utilization (Angel et al. 2002, Konietzny \& Greiner 2003, Simpson \& Wise 1990). Additionally, they are also able to form complexes with dietary proteins, starch and lipids as well as to inhibit a number of nutritionally important enzymes (De Rham \& Jost 1979, Kumar et al. 2010). Due to lack of phytase activity, organic phosphorous may pass through the digestive tract of non- 
ruminant animals undigested (poultry, pig, fish) - same situation in the human digestion tract. Therefore, in intensive livestock farming the feed must be supplemented with inorganic phosphate, and the phosphorus bound in phytate is excreted in the manure (Lei \& Porres 2003) causing numerous environmental problems. Furthermore, the increased emission of phosphorous often contributes to eutrophication of surface waters (Cao et al. 2007).

Phytase enzyme that is able to hydrolyse ester linkages in phytic acids, should serve as good catalists for release of organic phosphorous in feed or foodstuff, thus help to decrease environmental pollution problem. This enzyme may also have importance in human nutrition, and should help to decrease the risk of diseases in certain groups of people such as vegetarians or in the population of developing countries who usually consume high amount of plant-based foods.

It has been recognised that the sequential hydrolysis of phytate results different myoinositol phosphate intermediates that have health and pharmaceutical effects. Some clinical studies proved that these intermediates reduce the risk of colon cancer, the level of serum cholesterol and triglycerides in test animals, and reduce lipid peroxidation, and act as antioxidants (Kumar et al. 2010, Phillippy \& Graf 1997).

Phytase enzyme occurs widespread in the world, which results in the production of different source of enzyme. Although several strains of bacteria, yeasts and fungi have been used for production of phytase under different conditions, especially those originating from filamentous fungi have most commonly been employed for commercial production of this enzyme (Haefner et al. 2005). In submerged culture, different strains of Thermomyces lanuginosus produce some enzymes including amylolytic enzymes (Nguyen et al. 2000), $\alpha$-galactosidase (Rezessy-Szabó et al. 2007), $\beta$-galactosidase (Fischer et al. 1995), lipase (Arima et al. 1972), phytase (Gulati et al. 2007), xylanase (Singh et al. 2003) and protease ( $\mathrm{Li}$ et al. 1997). Technologically, phytases that are used as animal feed supplements should be able to withstand temperatures of $60^{\circ} \mathrm{C}$ to $90^{\circ} \mathrm{C}$, which may be reached during the feed pelleting process. Furthermore, enzymes originated from thermophilic organisms have been much more heat tolerant than ones from mesophilic or plant sources, thus these organisms should be ideal sources for production of enzyme.

In this work, production and partial characterisation of phytase from thermophilic fungus Thermomyces lanuginosus strain IMI 096218 on rice flour as fermentation substrate were focused.

\section{Materials \& Methods}

\section{Microorganisms and cultivation}

Thermomyces lanuginosus strains (ATCC 16455, ATCC 28083, ATCC 34626, ATCC 36350*, ATCC 38905, ATCC 44008*, ATCC 46882, ATCC 84400, CBS 218.34, CBS 288.54, CBS 395.62b*, DSM 5826*, IMI 096218*, IMI 158749*) were either provided by Dr. Bhat (marked with *, Institute of Food Research, Norwich, England) or purchased from different culture collections. Strains grew on Potato Dextrose Agar (PDA) at $47^{\circ} \mathrm{C}$ for $1-2$ days. Then they were stored at $4^{\circ} \mathrm{C}$ until use.

\section{Fermentation procedure for enzyme production}

Inoculum culture was prepared using $500 \mathrm{~mL}$ flasks filled with $150 \mathrm{~mL}$ broth containing $\left(\mathrm{g} \mathrm{L}^{-1}\right.$ ): glucose 20, L-asparagine 4.5, $\mathrm{KH}_{2} \mathrm{PO}_{4} 3.0, \mathrm{~K}_{2} \mathrm{HPO}_{4} 2.0, \mathrm{MgSO}_{4} \times 7 \mathrm{H}_{2} \mathrm{O}$ 0.5, Vogel's trace elements $1 \mathrm{~mL}$ (Vogel 1956). First, conidia were washed from the surface of PDA slant culture with $5 \mathrm{~mL}$ of $0.01 \%(\mathrm{w} / \mathrm{v})$ triton $\mathrm{x}-100$ solution and then transfer into flasks. The cultures were incubated in an orbital shaker with $200 \mathrm{rpm}$ at $47^{\circ} \mathrm{C}$ for $1-2$ days.

Phytase production was carried out in $500 \mathrm{~mL}$ Erlenmeyer flask containing $150 \mathrm{~mL}$ of fermentation medium with the following compounds $\left(\mathrm{g} \mathrm{L}^{-1}\right): \mathrm{MgSO}_{4} \times 7 \mathrm{H}_{2} \mathrm{O} 0.5 ; \mathrm{KCl} 0.5 ; \mathrm{FeSO}_{4}$ 0.1 and $\mathrm{NaNO}_{3} 8.6$ as mineral salts. The medium was supplemented with phytate containing crop or rice flour base on the individual situation of experiments. Fermentations were initiated with $5 \%$ (w/v) of 1-2-day old inoculum and then incubated in an orbital shaker at $47^{\circ} \mathrm{C}$ up to $2-7$ days. 


\section{Phytase activity assay}

Sample from fermentation broth was filtered to remove fungal mycelia and the phytase activity was assayed from the filtrate fraction using the method described by Engelen and coworkers (1994). The released phosphate develops yellow coloured complex with ammonium molibdate that was quantified spectrophotometrically at $415 \mathrm{~nm}$ using calibration curve prepared with inorganic phosphate under the same conditions. One unit of phytase activity was defined as the amount of enzyme capable of releasing one $\mu$ mol phosphate per min under the reaction conditions $\left(65^{\circ} \mathrm{C}, 10 \mathrm{~min}, \mathrm{pH} 5.5\right)$.

\section{Enzyme purification}

Extracellular proteins were recovered from cell-free ferment broth and precipitated by ammonium sulphate up to $80 \%$ saturation at $4^{\circ} \mathrm{C}$ for a night. The precipitated protein was collected by centrifugation $\left(17300 \mathrm{~g}, 20 \mathrm{~min}, 4^{\circ} \mathrm{C}\right)$ and then dissolving in $50 \mathrm{mM}$ sodium acetate buffer $(\mathrm{pH}$ 5.5). The crude enzyme was dialysed and concentrated by ultrafiltration using a $10 \mathrm{kDa}$ membrane cut out. Enzyme purification was achieved by combination different chromatographic columns connected to FPLC system.

The first step hydrophobic interaction chromatography was applied. Sample was loaded onto a Phenyl Sepharose column pre-equilibrated with $50 \mathrm{mM}$ sodium acetate buffer, $\mathrm{pH}$ 5.5, 1.3 M $\left(\mathrm{NH}_{4}\right)_{2} \mathrm{SO}_{4}$. The bounded protein was subsequently eluted with $50 \mathrm{mM}$ Na-acetate buffer at 3 $\mathrm{ml} / \mathrm{min}$ flow rate. Fractions with phytase activity were pooled and concentrated by ultrafiltration. The sample then was loaded onto a Phenyl Sepharose column pre-equilibrated with $50 \mathrm{mM}$ sodium acetate buffer, $\mathrm{pH} 5.51 .7 \mathrm{M}\left(\mathrm{NH}_{4}\right)_{2} \mathrm{SO}_{4}$. The elution was achieved as the same method. The active fractions were pooled, concentrated by ultrafiltration with an Amicon PM 10 membrane and loaded onto a Q-Sepharose ion-exchange column $(1 \mathrm{~cm} \mathrm{x} 25 \mathrm{~cm})$ pre-equilibrated with $50 \mathrm{mM}$ Tris/HCl buffer, $\mathrm{pH}$ 7.2. The column was washed with the same buffer and eluted with a linear gradient of 0$1 \mathrm{NaCl}$. Protein concentration was determined by Bradford assay (Bradford 1976).

\section{Characterization of purified phytase}

The effect of $\mathrm{pH}$ on phytase activity was assessed by using buffers between 1.5 and 9.0 of $\mathrm{pH}$ [sodium citrate/ $\mathrm{HCl}$ buffer ( $\mathrm{pH} 1.5$ to 3.5), sodium acetate buffer ( $\mathrm{pH} 3.5$ to 6.5), Trismaleate/ $\mathrm{NaOH}$ (pH 5.5 to 9.0)], and performing assays at $65^{\circ} \mathrm{C}$.

For determining optimum temperature for the activity of phytase, the enzyme assays were carried out in the temperature range between 35 and $90^{\circ} \mathrm{C}$ (sodium acetate buffer containing sodium phytate substrate, $\mathrm{pH}$ 5.5).

The thermostability of the phytase was achieved by incubating the enzyme at $55^{\circ} \mathrm{C}, 60^{\circ} \mathrm{C}$, $65^{\circ} \mathrm{C}$ at $\mathrm{pH}$ 3.5-7.5 (sodium acetate and $0.1 \mathrm{M}$ Tris-maleate/ $\mathrm{NaOH}$ ) buffers. The samples were withdrawn at regular intervals and residual phytase activity was measured at $65^{\circ} \mathrm{C}(\mathrm{pH} 5.5)$.

The effect of various metal ions on the enzyme activity by incorporating these into the reaction mixtures in concentration of $5 \mathrm{mM}$ except $\mathrm{Fe}^{2+}$ and $\mathrm{Fe}^{3+}$ ions where $1 \mathrm{mM}$.

Determination of kinetic constants was achieved over a range of sodium phytate substrate concentrations $(0.1-10 \mathrm{mM})$. The kinetic constants $\left(\mathrm{K}_{\mathrm{M}}\right.$ and $\left.\mathrm{V}_{\max }\right)$ were computed from a Lineweaver-Burk and Hanes-Woolf plot.

\section{Electrophoretic analysis}

Denaturing sodium dodecyl sulphate polyacrylamide gel electrophoresis (SDS-PAGE) was performed on $10 \%$ polyacrylamide gels with $0.1 \%$ SDS as described by Laemmli (1970). Protein bands were visualized by staining with Coomassie Brilliant Blue R-250.

\section{Statistical analysis}

In order to enhance data evaluation several statistical methods were performed. All data are presented as the mean and standard deviation (SD). The correlation between independent variables was tested by Pearson correlation test. Also two- and three-dimensional linear models were 


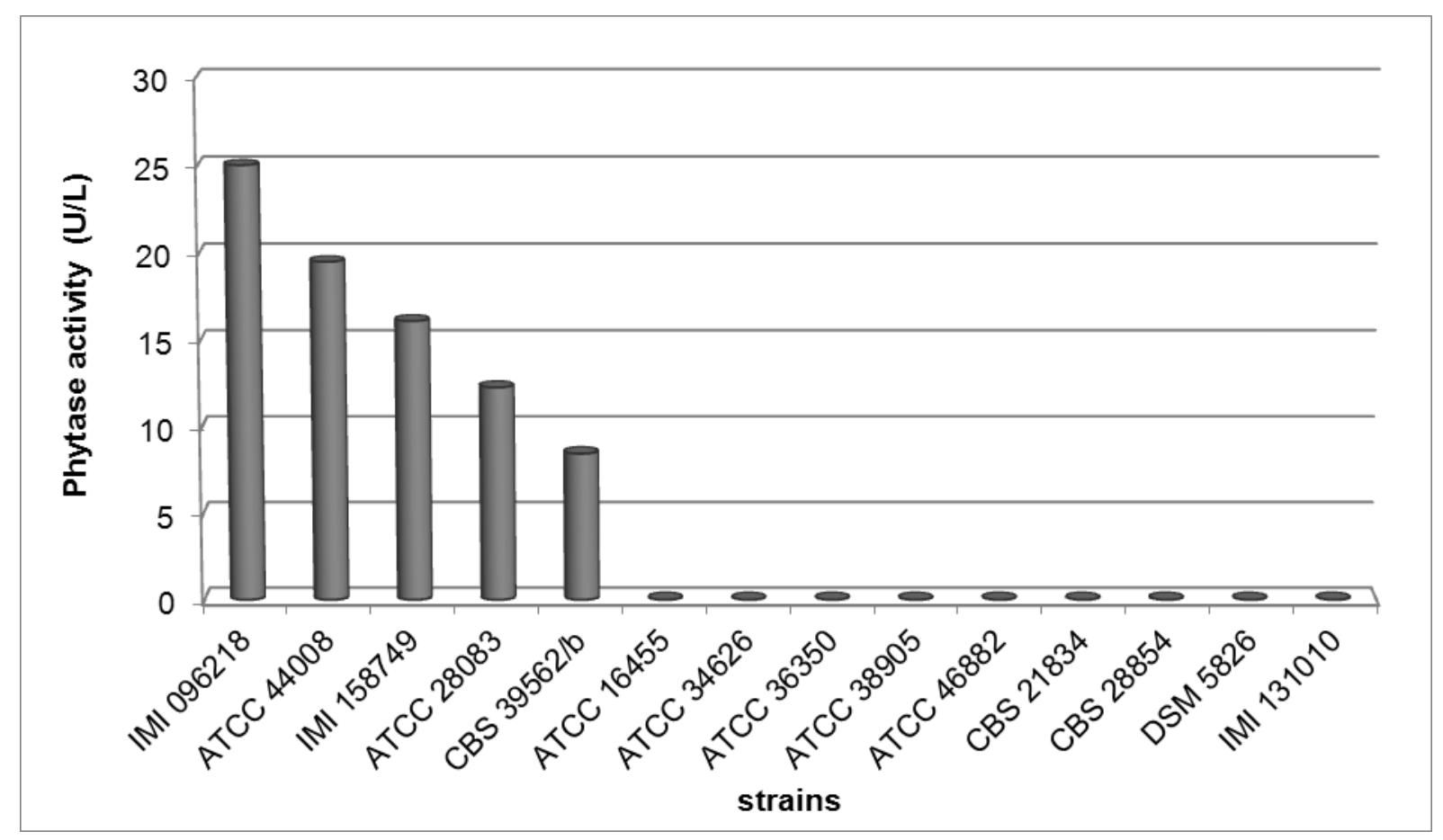

Fig. 1 - Screening of T. lanuginosus strains based on phytase activity $\left(47^{\circ} \mathrm{C}, 220 \mathrm{rpm}, 3 \%\right.$ corn flour, $48 \mathrm{~h}$ ).

performed to mention the connections of the variables. One-way analysis of variance (ANOVA), unpaired and paired Student's t-tests were done using Statistica 10.0 software package (StatSoft, USA). Generally, only $\mathrm{p}<0.05$ was accepted as the statistical significance level. The response surface method was applied to investigate the stability of enzyme (Rezessy-Szabó et al. 2007). The goodness of the fitted model was evaluated by regression analysis.

\section{Results \& Discussion}

\section{Production of extracellular phytase}

Screening works were done using fourteen Thermomyces lanuginosus strains from different culture collections on culture media containing $30 \mathrm{~g} \mathrm{~L}^{-1}$ corn flour as main carbon source and inducer. Phytase activity of extracellular fraction was assayed at different time periods of the fermentation process. Fig. 1 showed the results at $48^{\text {th }}$ hour of fermentation. Only 5 strains (IMI 096218, ATCC 44008, IMI 158749, ATCC 28083 and CBS 359.62/b) exhibited extracellular phytase activity and the T. lanuginosus IMI 096218 strain was proved to be the best one $\left(25 \mathrm{U} \mathrm{L}^{-1}\right)$ on the corn flour substrate. The effect of other natural substrate (rice flour) on secretion of phytase was also investigated. Rice flour was proved to be good substrate for production of phytase by Aspergillus niger (Bujna et al. 2013). In the case of T. lanuginosus mould, the enzyme production was also enhanced (generally increase in 2-5 times comparing with ones used standard media), when the medium was prepared with TRIS-maleate/ $\mathrm{NaOH}$ buffer $(\mathrm{pH}$ 7.5) and rice flour as natural substrates.

The effects of different agitation speed and concentration of rice flour on enzyme production were investigated. Based on our results, the optimal rice flour concentration was 5 (w/v)\%. It can be observed that using $220 \mathrm{rpm}$ agitation speed the maximal activity was achieved on the $4^{\text {th }}$ day of fermentation (Fig. 2), whereas at $120 \mathrm{rpm}$ agitation speed it should take 7 days. Application of $8(\mathrm{w} / \mathrm{v}) \%$ rice flour at $120 \mathrm{rpm}$ resulted as same enzyme activity on the $7^{\text {th }}$ day as at $220 \mathrm{rpm}$ on the $4^{\text {th }}$ day of fermentation. The medium containing $8(\mathrm{w} / \mathrm{v}) \%$ rice flour was rather viscous which makes agitation and aeration difficulties during submerged fermentation. 


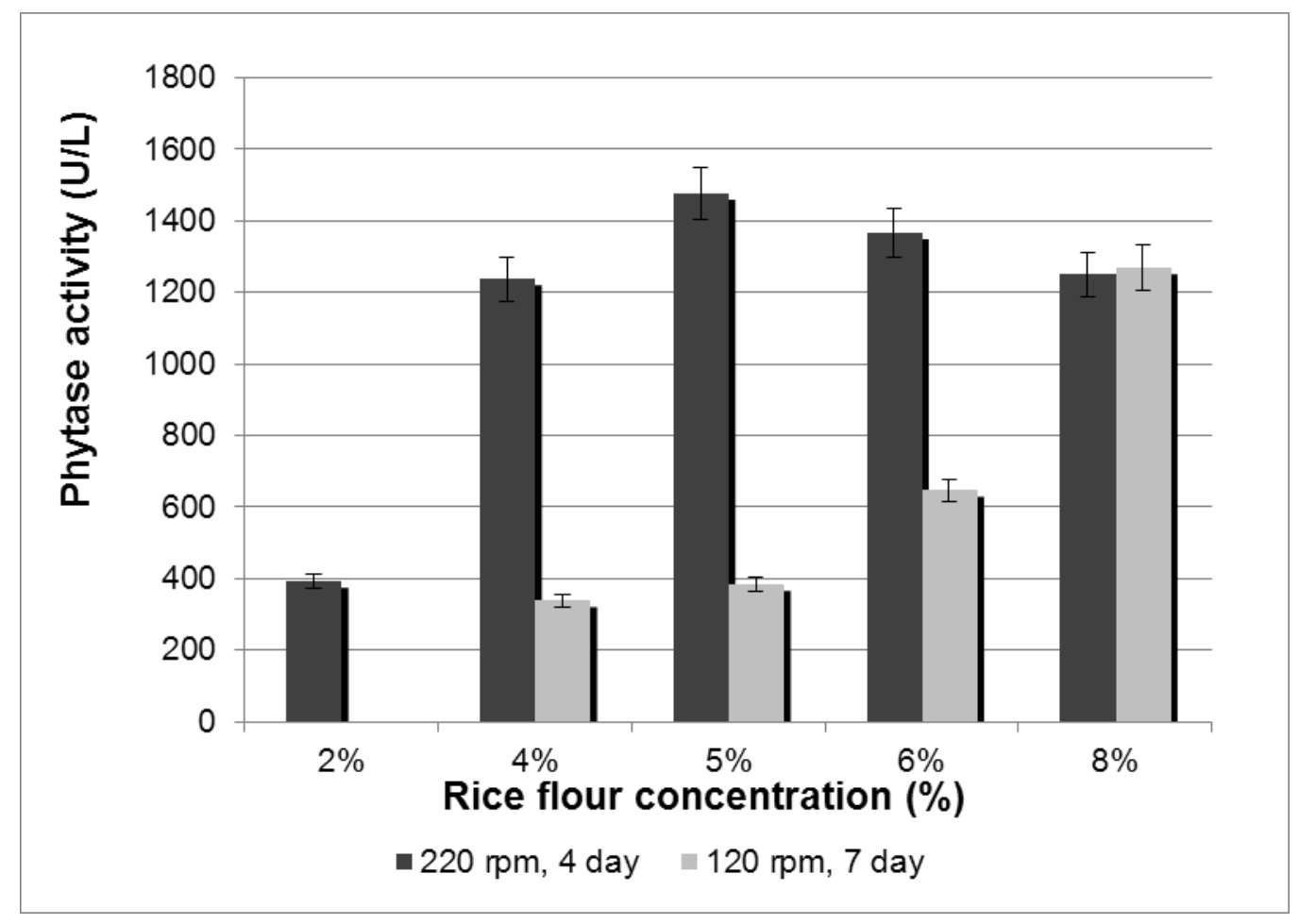

Fig 2 - Comparison of maximal phytase activity at different agitation speed (120 rpm and $220 \mathrm{rpm}$ ) and rice flour concentration.

However the high temperature and moisture are appropriate for thermophilic fungi-like compost where the concentration of $\mathrm{CO}_{2}$ inside composts can be as high as 10 to $15 \%$ (Maheshwari et al. 2000). Although $\mathrm{CO}_{2}$ is not regarded as a nutritional requirement for fungi, growth of $T$. lanuginosus was severely affected if the gas phase in the culture flask was devoid of $\mathrm{CO}_{2}$.

The effect of agitation speed on phytase production by Sporotrichum thermophile thermophilic fungi were investigated by Singh \& Satyanarayana (2012). They found that continuous increase in agitation rates from static conditions to $300 \mathrm{rpm}$ resulted gradually enzyme activity enhancement through the improved availability of oxygen and nutrients. The highest enzyme activity was measured at $250 \mathrm{rpm}$. Further increase in agitation rates caused a fall in the enzyme production, which could be due to disruption of fungal mycelium at very high agitation speeds, as well as shorter contact between cells and the medium, thus hindering the uptake of the nutrients. Our results were quietly closed to Singh \& Satyanarayana (2012), thus in further experiments phytase fermentations with Thermomyces lanuginosus IMI 096218 strain were hold on $220 \mathrm{rpm}$ during $7^{\text {th }}$ day fermentation

The effect of the fermentation medium supplemented with various additives such as Tween 80, citric acid and yeast extract in $0.1 \%$ concentration both in themselves and in all possible combinations on the production of enzyme was investigated (Table 1). Yeast extract alone has no significant increasing effect on the phytase activity, but together with Tween resulted more than $25 \%$ higher enzyme activity. These results are very similar to those reported by Dharmsthiti et al. (2004) who were enhanced phytase production of Pseudomonas putida applying $0.1 \%$ yeast extract, $0.1 \%$ citric acid and $0.1 \%$ Tween 80 altogether. Citric acid in concentration of $0.1 \%$ has strong inhibitory effect on phytase production of T. lanuginosus IMI 096218 strain. The activity was nearly $90 \%$ lower than control. The best result was achieved using Tween 80 . The presence of Tween 80 surfactant enhanced the secretion of extracellular phytase activity, and this effect was eliminated when combining with citric acid. This detergent was applied by Arnesen and co-workers (1998) for enhancing production and excretion of $\square$-amylase by Thermomyces lanuginosus and 2.7 times higher activity was obtained. Effects of different natures and concentration of Tweens on 
Table 1 Effects of supplementation with different additives on phytase activity in fermentation medium.

\begin{tabular}{ccccc}
\hline Experimental run & \multicolumn{3}{c}{ Concentration } & Effect \\
\cline { 2 - 4 } & Yeast extract & Tween 80 & Citric acid & \\
\hline 1 & $0.1 \%$ & - & - & - \\
2 & - & $0.1 \%$ & $0.1 \%$ & - \\
3 & - & - & - & + \\
4 & $0.1 \%$ & $0.1 \%$ & $0.1 \%$ & - \\
5 & $0.1 \%$ & $0.1 \%$ & $0.1 \%$ & - \\
6 & - & $0.1 \%$ & $0.1 \%$ & - \\
7 & $0.1 \%$ & - & - &
\end{tabular}

Table 2 Purification details of phytase from T. lanuginosus IMI 096218.

\begin{tabular}{|c|c|c|c|c|c|}
\hline Steps & $\begin{array}{l}\text { Total activity } \\
\text { (U) }\end{array}$ & $\begin{array}{l}\text { Total protein } \\
\quad(\mathrm{mg})\end{array}$ & $\begin{array}{l}\text { Specific } \\
\text { activity } \\
(\mathrm{U} / \mathrm{mg})\end{array}$ & $\begin{array}{c}\text { Yield } \\
(\%)\end{array}$ & Fold \\
\hline Culture broth & 1200 & 126.2 & 9,5 & 100 & 1 \\
\hline After precipitation & 493.9 & 35.7 & 13.8 & 41.2 & 1.5 \\
\hline $\begin{array}{l}\text { Hydrophobic interaction } \\
\text { chromatography }\end{array}$ & 121.8 & 4.5 & 27.0 & 10.2 & 2.8 \\
\hline Ion exchange chromatography & 61.5 & 0.7 & 86.7 & 5.1 & 9.1 \\
\hline
\end{tabular}

secretion of phytase enzyme by T. lanuginosus (Bujna et al. 2011) were also studies and the best result was obtained in the case of the addition of $0.1 \%$ Tween 40 surfactant to the fermentation medium.

\section{Purification and characterization of phytase enzyme}

The extracellular phytase from T. lanuginosus IMI 096218 strain growing under the optimized fermentation conditions was purified by a combination of chromatographic procedures after precipitation with ammonium sulphate. The phytase was purified about 9.1 fold with yield of $5.1 \%$ (Table 2). A phytase enzyme originated from Thermomyces lanuginosus isolated from soil completed with compost purified by Gulati and co-workers (2007) resulted $3.44 \%$ yield and 40.75 fold. The reason of the higher purification fold may be due to the initial protein synthetized on wheat bran during solid state fermentation. The ratio of phytase is lower in the crude protein, which leads lower fold.

The purified enzyme was checked by polyacrylamide gel electrophoresis. The molecular mass of purified phytase was estimated to be approximately $60 \mathrm{kDa}$ (data are not shown). This result is closed to one reported by Berka and co-workers (1998) as well as to one published by Gulati and co-workers (2007).

The purified phytase enzyme exhibited an optimal $\mathrm{pH}$ value at $\mathrm{pH}$ 5.5. Chadha and coworkers (2004) produced phytase from Rhizomucor pusillus by solid-state fermentation technology and partially purified. The optimal $\mathrm{pH}$ of the enzyme preparation was $\mathrm{pH} 5.4$, but $80 \%$ of maximal activity was assayed in the wide range of $\mathrm{pH}$ (pH 3-7.8). Similar results were observed in the case of phytase originated from thermophilic fungi Aspergillus fumigatus, Myceliophthora thermophile and Sporotrichum thermophile (Singh \& Satyanarayana 2011, Wang et al. 2007, Wyss et al. 1999) and optimal $\mathrm{pH}$ was 5.5. The $\mathrm{pH}$ optimum at phytase from Thermomyces lanuginosus TL-7 mutant strain and Thermoascus aurantiacus thermophilic fungi were determined at $\mathrm{pH}$ 5.0, respectively (Gulati et al. 2007, Nampoothiri et al. 2004). Another recombinant Thermomyces lanuginosus strain's phytase enzyme $\mathrm{pH}$ optimum was at $\mathrm{pH} 7$ (Berka et al. 1998). 


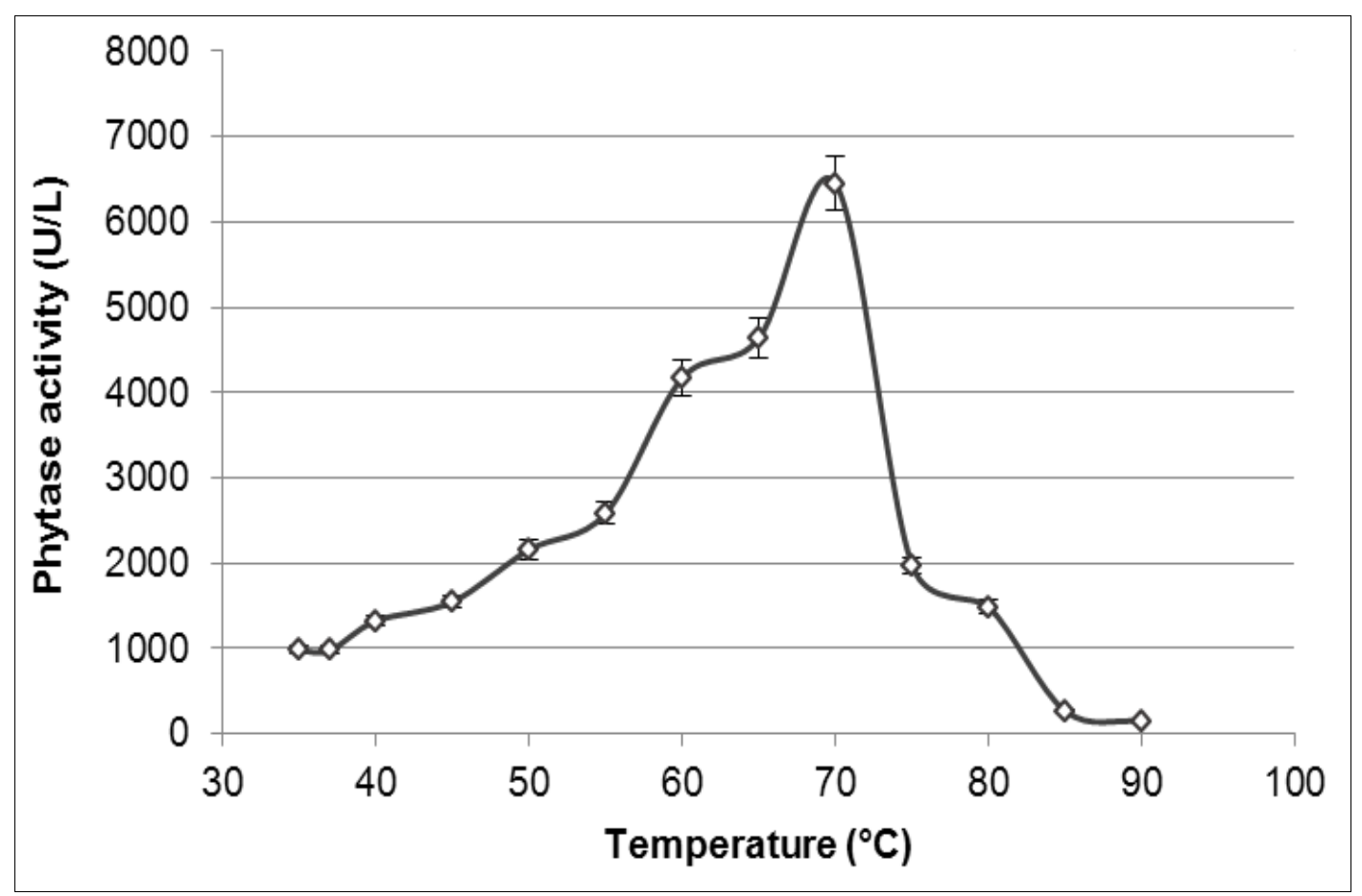

Fig 3 - The effect of temperature on phytase from T. lanuginosus IMI 096218 (pH 5.5).

The optimum temperature of phytase from $T$. lanuginosus IMI 096218 was measured at $70^{\circ} \mathrm{C}$ (Fig 3). Similar results were determined in case of partially purified phytase from Rhizomucor pusillus (Chadha et al. 2004) and T. lanuginosus TL-7 mutant (Gulati et al. 2007). Among the other thermophilic fungi Thermoascus aurantiacus, Sporotrichum thermophile (Nampoothiri et al. 2004) and Thermomyces lanuginosus (Berka et al. 1998) reached the maximal activity at $55^{\circ} \mathrm{C}, 60{ }^{\circ} \mathrm{C}$, and $65^{\circ} \mathrm{C}$ respectively.

The high temperature optimum and thermostability are particularly important features of phytases applied in livestock as feed pelleting, when it is commonly performed at temperatures between $65{ }^{\circ} \mathrm{C}$ and $95{ }^{\circ} \mathrm{C}$ (Vohra \& Satyarayana 2003). The stability of purified phytase was investigated at different temperatures $\left(55^{\circ} \mathrm{C}, 60^{\circ} \mathrm{C}, 65^{\circ} \mathrm{C}\right.$ ) and $\mathrm{pH}$ (in range from $\mathrm{pH} 3.5$ to $\mathrm{pH} 7.5$ with stepwise $\mathrm{pH}$ 0.5). The results were evaluated using response surface method where independent factors were $\mathrm{pH}$ and temperature, as well as the half-life time and the initial inactivation slope of enzyme were selected as dependent variables. Full quadratic polynomial models were applied to describe the half-life time and initial inactivation slope, respectively.

It can be observed that among the tested temperatures the enzyme most stable at $55^{\circ} \mathrm{C}$ (Fig 4). The half-life times of enzyme when incubation at $\mathrm{pH}$ range of $\mathrm{pH} 5.5$ and $\mathrm{pH} 7.5$, as well as at $55^{\circ} \mathrm{C}$ varied from $135 \mathrm{~min}$ up to $148 \mathrm{~min}$. The stability has decreased when the temperature increase or the $\mathrm{pH}$ change to more acidic. The half-life times were $106-107 \mathrm{~min}$ at $60{ }^{\circ} \mathrm{C} \mathrm{pH} \mathrm{6-6.5}$ and $45-46 \mathrm{~min}$ at $65^{\circ} \mathrm{C} \mathrm{pH} 5.5-6.0$, respectively. The purified enzyme loses all its activity at $\mathrm{pH} 3.5$ or lower $\mathrm{pH}$. The highest stability of phytase originated from filamentous fungi was determined by Pasamontes and co-workers (1997). They found that the phytase from a gene manipulated Aspergillus fumigatus strain retained $90 \%$ activity at $100{ }^{\circ} \mathrm{C}$ during 20 minutes.

The initial inactivation velocity was also affected by temperature and $\mathrm{pH}$. Incubation of enzyme at $56{ }^{\circ} \mathrm{C}$ in the range of $\mathrm{pH}$ from 4.7 to 7.0 resulted slowly lose of activity. The purified phytase inactivates drastically in the first stage where incubation of it at temperature higher than 65 ${ }^{\circ} \mathrm{C}$ or/and at $\mathrm{pH}<3$.

Our results were confirmed experimentally by carrying out some runs at $\mathrm{pH} 5.5$ and $70{ }^{\circ} \mathrm{C}, \mathrm{pH}$ 6.0 and $60{ }^{\circ} \mathrm{C}, \mathrm{pH} 6.5$ and $55^{\circ} \mathrm{C}, \mathrm{pH} 6.5$ and $60{ }^{\circ} \mathrm{C}, \mathrm{pH} 7.5$ and $55^{\circ} \mathrm{C}$, respectively. 


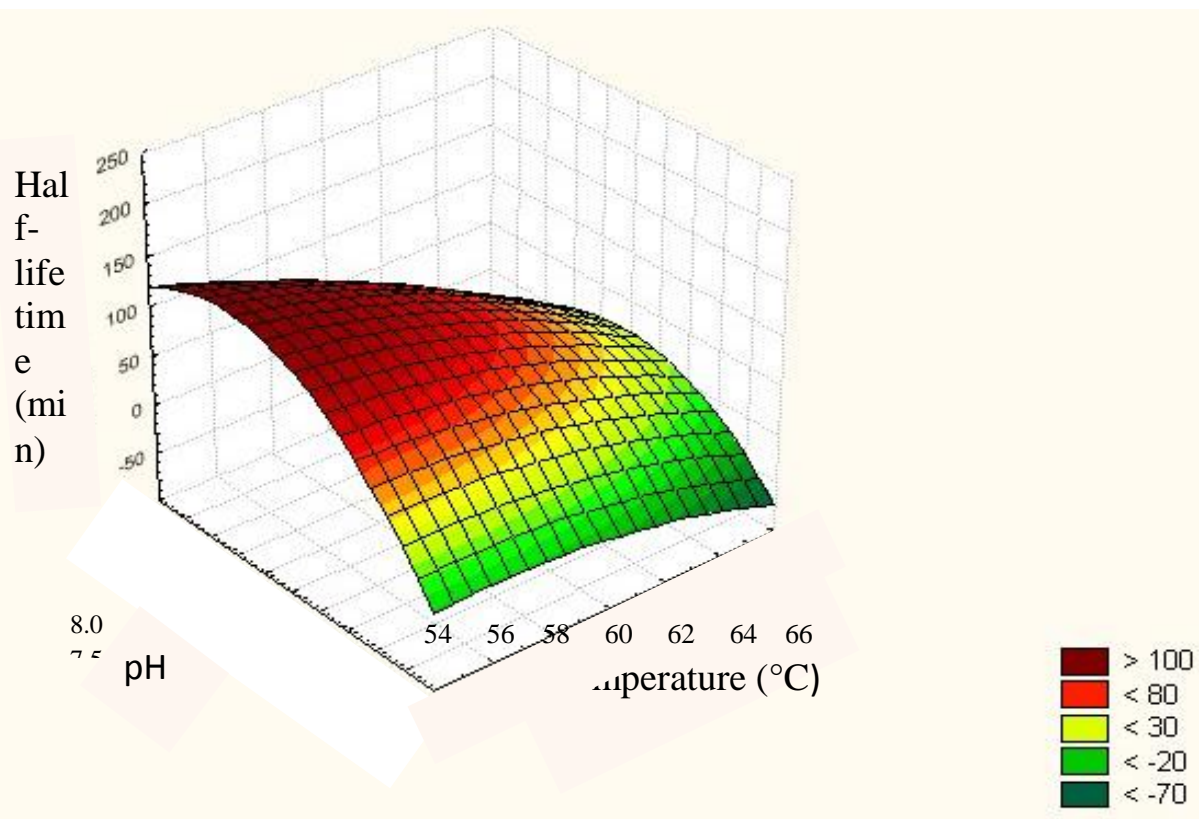

Fig 4 - The half-life time (min) of phytase from T. lanuginosus IMI 096218 in function of $\mathrm{pH}$ and temperature.

Table 3 Kinetic parameters of different source of phytase on sodium phytate substrate (with Lineweaver-Burk linearization method).

\begin{tabular}{llll}
\hline Producing strain & $\mathrm{K}_{\mathrm{M}}(\mathrm{mM})$ & $\mathrm{V}_{\max }$ & References \\
\hline A. ficuum & 0.295 & $55.9 \mathrm{nmol} / \mathrm{min}$ & Zhang et al. 2010 \\
A. oryzae & 0.33 & - & Shimizu et al. 1993 \\
A. terreus 9A1 & 0.0106 & - & Wyss et al. 1999 \\
A. terreus CBS & 0.0232 & - & Wyss et al. 1999 \\
A. niger ATCC 9142 & 0.1 & $7 \mathrm{nmol} / \mathrm{min}$ & Casey \& Walsh 2003 \\
T. lanuginosus TL-7 & 0.00455 & $0.833 \mu \mathrm{M} / \mathrm{min}$ & Gulati et al. 2007 \\
A. niger NCIM 563 PhyI & 2.01 & $5.018 \mu \mathrm{mol} / \mathrm{min}$ & Soni et al. 2010 \\
PhyII & 0.145 & $1.671 \mu \mathrm{mol} / \mathrm{min}$ & Our study \\
T. lanuginosus IMI 096218 & 0.285 & $0.126 \mu \mathrm{M} / \mathrm{min}$ & \\
\hline
\end{tabular}

Gulati and co-workers (2007) investigated the $\mathrm{pH}$ and thermostability of phytase from $T$. lanuginosus TL-7 mutant strain. It was observed that despite of optimum $\mathrm{pH} 5.0$, the enzyme much more stable at $\mathrm{pH}$ 7.0. The thermostability of phytase from Sporotrichum thermophile determined by Singh \& Satyanarayana (2009). The retained activity was $100 \%$ during 5 hours incubation at 60 ${ }^{\circ} \mathrm{C}$. The half-life time was 16 hour and $90 \mathrm{~min}$ at $60{ }^{\circ} \mathrm{C}$ and $80^{\circ} \mathrm{C}$, respectively. The gene (Ncphy) encoding a putative phytase in Neurospora crassa was cloned and expressed in Pichia pastoris by Zhou and co-workers (2006). Experiments on the thermostability of the purified rNcPhy revealed that the initial activity after exposure to $80{ }^{\circ} \mathrm{C}$ for 10,20 or 60 min retained $76 \%, 58 \%$ or $43 \%$, respectively. It means that the phytase from T. lanuginosus IMI 096218 strain is less thermostable as ones from originated mutant or genetically modified strains.

Kinetic parameters of phytase originating from T. lanuginosus IMI 096218 strain on sodium phytate substrate were determined by linear Lineweaver-Burk plot: $\mathrm{K}_{\mathrm{M}}=0.285 \mathrm{mM}$, $\mathrm{Vmax}=0.126$ $\mu \mathrm{M} / \mathrm{min}$, and Hanes-Woolf plot: $\mathrm{K}_{\mathrm{M}}=0.312 \mathrm{mM}, \mathrm{V}_{\max }=0.132 \mu \mathrm{M} / \mathrm{min}$. Kinetic parameters of phytases from different sources on sodium phytate substrate can be seen in Table 3 . The $K_{M}$ value in our case was similar with the ones from A. ficuum $(0.295 \mathrm{mM}$, Zhang et al. 2010) and A. orzyae (0.33 mM, Shimizu et al. 1993), meaning similar affinity to sodium phytate substrate. The phytase from T. lanuginosus TL-7 strain exhibited significantly higher affinity $\left(\mathrm{K}_{\mathrm{M}} 0.00455 \mathrm{mM}\right.$, Gulati et al. 2007) to substrate than other ones from moulds. 


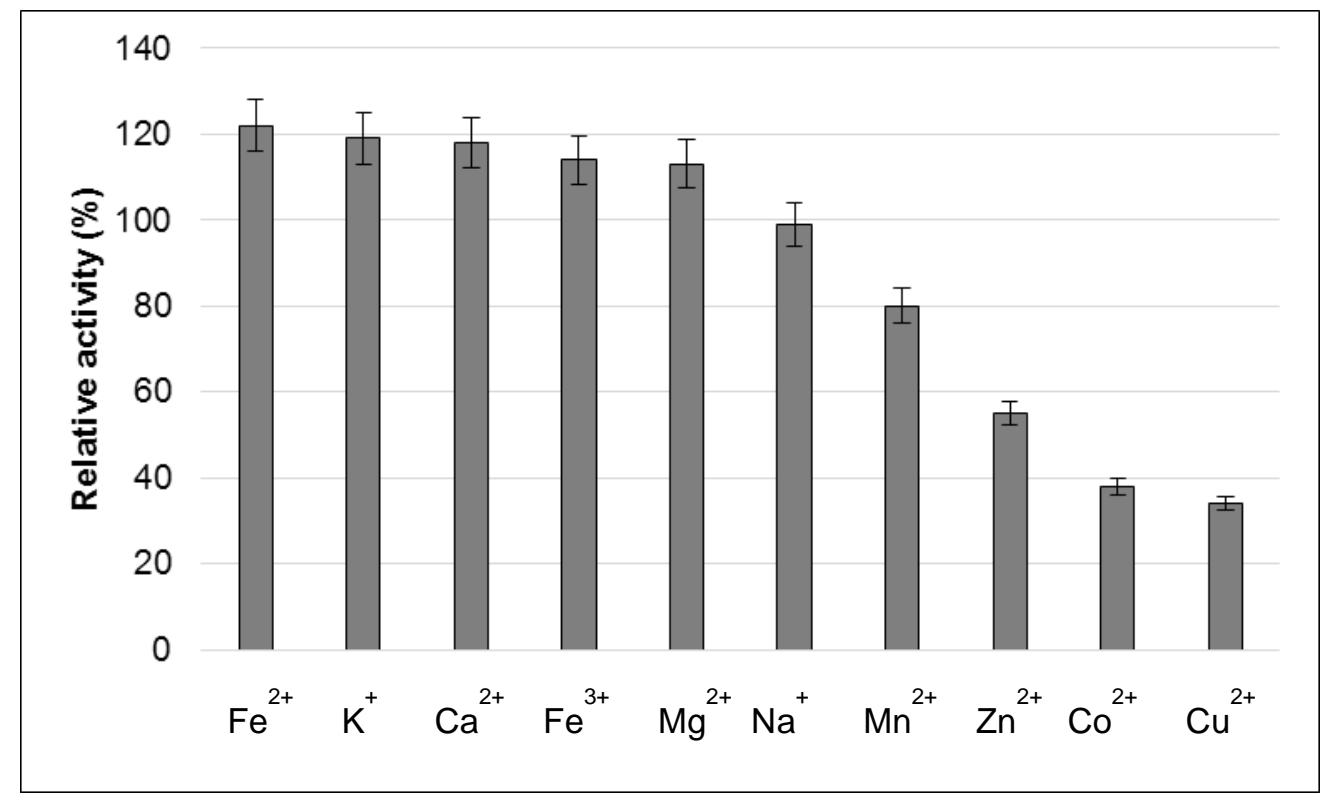

Fig 5 - Effect of metal ions on purified phytase activity from T. lanuginosus IMI 096218. 100\% phytase activity was obtained when phytase assay was undertaken in the absence of metal ions (Concentration: $5 \mathrm{mM}$, in the cases of $\mathrm{Fe}^{2+}$ and $\mathrm{Fe}^{3+}: 1 \mathrm{mM}$ ).

Effects of various metal ions on enzyme activity were investigated. Results in relative activity are on Figure 5, where the run without metal ions serve as control. The presence of $1 \mathrm{mM}$ $\mathrm{Fe}^{2+}, \mathrm{Fe}^{3+}$ and $5 \mathrm{mM} \mathrm{K}, \mathrm{Ca}^{2+}$ and $\mathrm{Mg}^{2+}$ ions resulted in $13-22 \%$ increase of activity, whereas the presence of $5 \mathrm{mM} \mathrm{Zn}{ }^{2+}, \mathrm{Ag}^{+}, \mathrm{Co}^{2+}$ and $\mathrm{Cu}^{2+}$ ions strongly inhibited the enzyme reaction. In these cases, the residual activities were $55 \%, 49 \%, 38 \%$ and $34 \%$, respectively. $\mathrm{Ca}^{2+}$ ions have important role in catalytic property of phytase, mainly in beta-propeller phytases that are especially isolated from Bacillus. The thermostable phytase from Bacillus amyloliquefaciens DS11 hydrolyzes phytate to less phosphorylated myo-inositol phosphates in the presence of $\mathrm{Ca}^{2+}$. Oh and co-workers (2001) were observed that Bacillus amyloliquefaciens DS11 thermostable phytase enzyme activity follows a rapid equilibrium ordered mechanism in which binding of $\mathrm{Ca}^{2+}$ to the active site is necessary for the essential activation of the enzyme. $\mathrm{Ca}^{2+}$ turned out to be also required for the substrate because the phytase is only able to hydrolyze the calcium-phytate complex. In fact, the excess of both $\mathrm{Ca}^{2+}$ and free phytate that do not make complex with each other are competitive inhibitors (Oh et al. 2001). The influence of zinc, iron, copper, magnesium and calcium has potentially significances with regard to applicability in animal feed. In contrast of our results, Wyss et al. (1999) reported that the $\mathrm{Fe}^{2+}$ and $\mathrm{Fe}^{3+}$ ions have inhibitory effect on phytase (originated from different fungi $A$. fumigatus, E. nidulans, A. niger, A. terreus) activity in concentration of $1 \mathrm{mM}$. Just like $\mathrm{Cu}^{2+}$ and $\mathrm{Mn}^{2+}$ ions, which have inhibitory effect on phytase originated from T. lanuginosus IMI 096218 strain, where nearly $70 \%$ decrease in activity observed with $\mathrm{Cu}^{2+}$ ions, and $20 \%$ in the presence of $\mathrm{Mn}^{2+}$ in concentration of $5 \mathrm{mM}$. Addition of $\mathrm{Zn}^{2+}, \mathrm{Ag}^{+}$and $\mathrm{Co}^{2+}$ ions resulted inhibitory effect on phytase activity. Only 55\%, 49\% and $38 \%$ activity, respectively, were retained when addition of these ions. $\mathrm{Na}^{+}$ions have no effect on phytase activity of T. lanuginosus IMI 096218.

$\mathrm{Cu}^{2+}$ ions in concentration of $1 \mathrm{mM}$ inhibited phytase from Neurospora crassa expressed in Pichia pastoris, and $\mathrm{Ca}^{2+}, \mathrm{Mg}^{2+}, \mathrm{Fe}^{2+}, \mathrm{Co}^{2+}, \mathrm{Mn}^{2+}, \mathrm{Zn}^{2+}$ ions have no significant effect on enzyme activity (Zhou et al. 2006). $\mathrm{Cu}^{2+}$ ions have also inhibitory effect on phytase from Thermomyces lanuginosus TL-7 mutant strain, but each of $\mathrm{Ca}^{2+}, \mathrm{Mg}^{2+}, \mathrm{Fe}^{2+}, \mathrm{K}^{+}, \mathrm{Mn}^{2+}, \mathrm{Na}^{+}, \mathrm{Ba}^{+}, \mathrm{Zn}^{2+}$ ions decrease the enzyme activity in concentration of $5 \mathrm{mM}$ (Gulati et al. 2007). The enzyme activity of this mutant strain showed the greatest decrease in case of $\mathrm{Mg}^{2+}$ ions, while during at our examined enzyme the use of $\mathrm{Mg}^{2+}$ increased the activity by 13\%. Singh \& Satyanarayana (2009) reached enhanced phytase activity in case of Sporotrichum thermophile, in presence of magnesium ions, 
and all of the tested ions have inhibitory effect in concentration of $5 \mathrm{mM} . \mathrm{Zn}^{2+}$ and $\mathrm{Fe}^{3+}$ ions had the greatest inhibitory effect on enzyme (40-60\% decrease) similarly results in case of phytase from T. lanuginosus IMI 096218. The relative activity decreased to $55 \%$ in presence of $\mathrm{Zn}^{2+}$.

Our findings suggest that the inhibitory effect is depends on not only the applied metal ion concentration, but also on nature of origin such as the genetic structure of microorganisms or the individual strains.

\section{Conclusion}

Thermophilic fungus Thermomyces lanuginosus IMI 096218 secretes high level of extracellular phytase on medium containing rice flour as main carbon source, reaching $25 \mathrm{U} \mathrm{L}^{-1}$. Thus, this naturally available substrate may serve cheap raw material for phytase production in fermentation process. The characteristics of this phytase were much more closed to ones from $A$. niger or $A$. oryzae than on from genetically modified $T$. lanuginosus TL-7 strain. Since the phytase from T. lanuginosus IMI 096218 strain had high specific activity $\left(87 \mathrm{U} \mathrm{mg}^{-1}\right)$ as well as is stable for 1-2 hours at about $58-60^{\circ} \mathrm{C}$, it can be considered as a potential commercially viable candidate in animal nutrition and/or production of some intermediates for medical applications.

\section{References}

Angel R, Tamim NM, Applegate TJ, Dhandu AS, Ellestad LE. 2002 - Phytic acid chemistry: Influence on phytin-phosphorus availability and phytase efficacy. The Journal of Applied Poulty Research 11, 471-480.

Arima K, Liu WH, Beppu T. 1972 - Studies on the lipase of thermophilic fungus Humicola lanuginosa. Agricultural and Biological Chemistry 36, 893-895.

Arnesen S, Eriksen SH, Olsen J, Jensen J. 1998 - Increased production of $\alpha$-amylase from Thermomyces lanuginosus by the addition of Tween 80. Enzyme and Microbial Technology 23, 249-252.

Berka RM, Rey MW, Brown KM, Byun T, Klotz AV. 1998 - Molecular Characterization and Expression of a Phytase Gene from the Thermophilic Fungus Thermomyces lanuginosus. Applied and Environmental Microbiology 64, 4423-4427.

Bradford MM. 1976 - Rapid and sensitive method for the quantitation of microgram quantities of protein utilizing the principle of protein-dye binding. Analitical Biochemistry 72, 248-254

Bujna E, Kukovics F, Nguyen QD, Rezessy-Szabó JM. 2013-Rice flour as potential carbon source for production of phytase by Aspergillus niger. Acta Alimentaria 42, 1-9.

Bujna E, Siklodi C, Rezessy-Szabó JM. 2011 - Effects of surfactants on production of phytase from Thermomyces lanuginosus. Acta Microbiologica et Immunologica Hungarica 58, 130.

Cao L, Wang W, Yang C, Yang Yi, Diana J, Yakupitiyage A, Luo Z, Li D. 2007 - Application of microbial phytase in fish feed. Enzyme and Microbial Technology 40, 497-507.

Casey A, Walsh G. 2003 - Purification and characterization of extracellular phytase from Aspergillus niger ATCC 9142. Bioresource Technology 86, 183-188.

Chadha BS, Gulati H, Mandeep M, Saini HS, Singh N. 2004 - Phytase production by thermophilic fungus, Rhizomucor pusillus. Word Journal of Microbiology and Biotechnology 20, 105109.

De Rham O, Jost T. 1979 - Phytate protein interactions in soybean extracts and low-phytate soy protein products. Journal of Food Science 44, 596-600.

Dharmsthiti S, Chalermpornpaisarn S, Kiatiyajarn M, Chanpokapaiboon A, Klongsithidej Y, Techawiparut J. 2004 - Phytase production from Pseudomonas putida harbouring Escherichia coli app A. Process Biochemistry 40, 789-793.

Engelen AJ, Van Der Heeft FC, Randsdorp PHG, Smit ELC. 1994 - Simple and rapid determination of phytase activity. Journal of AOAC International 77, 760-764.

Fischer L, Scheckermann C, Wagner F. 1995 - Purification and characterization of a thermotolerant $\beta$-galactosidase from Thermomyces lanuginosus. Applied and Environmental 
Microbiology 61, 497-1501.

Gulati HK, Chadha BS, Saini HS. 2007 - Production, purification and characterisation of Thermomyces lanuginosus TL-7. Acta Microbiologica et Immunologica Hungarica 54, 121128.

Haefner S, Knietsch A, Scholten E, Braun J, Lohscheidt M, Zelder O. 2005 - Biotechnological production and application of phytase. Applied Microbiology and Biotechnology 68, 588597.

Konietzny U, Greiner R. 2003 - Phytic acid: Nutritional impact. 4555-4563. p. In: Caballero B., Trugo L, Finglas P. Encyclopaedia of food science and nutrition, London: Elsevier.

Kumar V, Sinha AK, Makkar HPS, Becker K. 2010 - Dietary roles of phytate and phytases in human nutrition: A review. Food Chemistry 120, 945-959.

Laemmli UK. 1970 - Cleavage of structural proteins during the assembly of the head of bacteriophage T4. Nature 227, 680-685.

Lei XG, Porres JM. 2003 - Phytase enzymology, applications, and biotechnology. Biotechnology Letters 25, 1787-1794.

Li J, Hegeman CE, Hanlon RW, Lacy GH, Denbow DM, Grabau EA. 1997 - Secretion of active recombinant phytase from soybean cell suspension cultures. Plant Physiology, 114, 1-9. p.

Loewus F. 2002 - Biosynthesis of phytate in food grains and seeds. p53-61. In: Reddy N.R., Sathe S.K. Food phytates. Boca Raton, Florida, USA: CRC Press.

Maheshwari R, Bharadwaj G, Bhat MK. 2000 - Thermophilic Fungi: Their Physiology and Enzymes. Microbiology and Molecular Biology Reviews 64, 461-488.

Nampoothiri KM, Tomes GJ, Roopesh K, Szakacs G, Nagy V, Soccol CR, Pandey A. 2004 Thermostable Phytase Production by Thermoascus aurantiacus in Submerged Fermentation. Applied Biochemistry and Biotechnology 118, 206-214.

Nguyen DQ, Rezessy-Szabó JM, Hoschke Á. 2000 - Optimisation of composition of media for the production of amylolytic enzymes by Thermomyces lanuginosus ATCC 34626. Food Technology and Biotechnology 38, 229-234.

Oh BC, Chang BS, Park KH, Ha NC, Kim HK, Oh BH, Oh TK. 2001 - Calcium-dependent catalytic activity of a novel phytase from Bacillus amyloliquefaciens DS11. Biochemistry 40, 9669-76.

Pasamontes L, Haiker M, Wyss M, Tessier M, Van Loon APGM. 1997 - Gene cloning, purification, and characterization of a heat-stable phytase from the fungus Aspergillus fumigatus. Applied and Environmental Microbiology 63, 1696-1700.

Phillippy BQ, Graf E. 1997 - Antioxidant functions of inositol 1,2,3-trisphosphate and inositol 1,2,3,6-tetrakisphosphate. Free Radical Biology and Medicine. 22, 939 - 946.

Rezessy-Szabó JM, Nguyen, QD, Hoschke Á, Braet C, Hajós Gy, Claeyssens M. 2007 - A novel thermostable alpha-galactosidase from the thermophilic fungus Thermomyces lanuginosus CBS 395.62/b: purification and characterization. Biochimica and Biophysica Acta 1770, $55-62$.

Shimizu M. 1993 - Purification and characterization of phytase and acid phosphatase produced by Aspergillus oryzae K1. Bioscience, Biotechnology and Biochemistry 57, 1364-1365.

Simpson CJ, Wise A. 1990 - Binding of zinc and calcium to inositol phosphates (phytate) in vitro. British Journal of Nutrition, 64, 225-232.

Singh B, Satyanarayana T. 2009 - Characterization of a HAP-phytase of a thermophilic mould Sporotrichum thermophile. Bioresource Technology 100, 2046-51.

Singh B, Satyanarayana T. 2011 - Phytases from thermophilic molds: Their production, characteristics and multifarious applications. Process Biochemistry 46, 71391-1398.

Singh B, Satyanarayana T. 2012 - Production of phytate-hydrolyzing enzymes by thermophilic moulds. African Journal of Biotechnology 11,12314-12324.

Singh S, Madlala AM, Prior BA. 2003 - Thermomyces lanuginosus: properties of strains and their hemicellulases. FEMS Microbiology Reviews 27, 3-16. 
Soni SK, Magdum A, Khire JM. 2010 - Píurification and characterization of two distinct acidic phytases with broad $\mathrm{pH}$ stability from Aspergillus niger NCIM 563. World Journal of Microbiology and Biotechnology 26, 2009-2018.

Vogel HJ. 1956 - A convenient growth medium for Neurospora (Medium N). Microbial Genetics Bulletin 13, 42-43

Vohra A, Satyanarayana T. 2003 - Phytases: Microbial sources, production, purification and potential biotechnological applications. Critical Reviews in Biotechnology 23, 29-60.

Wang Y, Gao X, Su Q, Wu W, An L. 2007 - Cloning, expression, and enzyme characterization of an acid heat-stable phytase from Aspergillus fumigatus WY-2. Current Microbiology 55, $65-70$.

Wyss M, Brugger R, Kronenberger A, Remy R, Fimbel R, Oesterhelt G, Lehmann M, Van Loon APGM. 1999 - Biochemical characterization of fungal phytases (myo-inositol hexakisphosphate phosphohydrolase): Catalytic properties. Applied and Environmental Microbiology 65, 367-373.

Zhang GQ, Dong XF, Wang ZH, Zhang Q, Wang HX, Tong JM. 2010 - Purification, characterization, and cloning of a novel phytase with low $\mathrm{pH}$ optimum and strong proteolysis resistance from Aspergillus ficuum NTG-23. Bioresource Technology 11, 412531.

Zhou XL, Shen W, Zhuge J, Wang ZX. 2006 - Biochemical properties of a thermostable phytase from Neurospora crassa. FEMS Microbiology Letters, 258, 61-66. 